\title{
The Influence of Judicial Adjudicators on the Uncertainty of Judicial Decisions
}

\author{
Yueqin Chen ${ }^{1}$, Zheng Zang ${ }^{2, *}$ \\ ${ }^{1}$ School of Journalism and Culture Communication, Zhongnan University of Economics and Law, Wuhan, China \\ ${ }^{2}$ School of Philosophy, Zhongnan University of Economics and Law, Wuhan, China
}

Email address:

buhle@qq.com (Yueqin Chen), zzhso@qq.com (Zheng Zang)

${ }^{*}$ Corresponding author

\section{To cite this article:}

Yueqin Chen, Zheng Zang. The Influence of Judicial Adjudicators on the Uncertainty of Judicial Decisions. Humanities and Social Sciences. Vol. 9, No. 4, 2021, pp. 91-96. doi: 10.11648/j.hss.20210904.13

Received: June 25, 2021; Accepted: July 14, 2021; Published: July 22, 2021

\begin{abstract}
One of the fundamental values of the existence of justice is that it psychologically satisfies the human need for stability and certainty, so that imbalances of power and responsibility can be balanced and disputes can be settled. Judicial justice is reflected in the entire process of judicial adjudication, which is subject to uncertainty. Between the two major uncertainties of judicial adjudication - the uncertainty of the rules of judicial adjudication and the uncertainty of the decision of judicial adjudicators - this article focuses on the latter by classifying and analyzing two major aspects, namely internal and external factors. As individuals in the secular world, judicial adjudicators have different knowledge backgrounds, various levels of experience and competence, distinctive institutional deficiencies, and dissimilar motivations for their interests, so that they perceive and apply the rules of adjudication differently, resulting in different outcomes, thus leading to the uncertainty of judicial adjudication. It is of course necessary for judges to maintain their independence, enforce the law strictly and administer justice impartially, and contribute to the establishment of a society governed by the rule of law, but it is even more necessary for us to create conditions to enhance judicial independence and impartiality through judicial reform, so as to reduce the uncertainty of judicial decisions. This paper proposes some countermeasures on how to reduce the uncertainty of judicial adjudication.
\end{abstract}

Keywords: Judicial Decisions, Uncertainty, Judicial Adjudicators, Judicial Independence

\section{Introduction}

Justice is done throughout the process of adjudication, but there is too much uncertainty in the process of adjudication. Uncertainty in judicial adjudication mainly includes uncertainty in the rules of judicial adjudication and uncertainty in the decisions of judicial adjudicators. The rules of judicial adjudication are general rules with universal significance summarized and abstracted in the process of dynamic development, which do not have absolute certainty in themselves. Meanwhile, the level of understanding of the rule makers (i.e., legislators) determines the difference between the expectations and results of the rules in judicial practice. Furthermore, the rules of justice themselves are general, abstract, principled, ambiguous and lagging, which makes them uncertain. As individuals in the secular world, judicial adjudicators have different knowledge backgrounds, various levels of experience and competence, distinctive institutional deficiencies, and dissimilar motivations for their interests, so that they perceive and apply the rules of adjudication differently, resulting in different outcomes, thus leading to the uncertainty of judicial adjudication.

Using a qualitative approach, in the studies of Mexico and Guatemala, Pásara used text analysis to argue that the formal structure of sentences and judges' interpretation of legal norms and evidence presented by litigants are relevant dimensions contributing to the quality of judicial decisions. $[1,2]$ The legal truth reached by legal facts is uncertain. Legal truth can be infinitely close to objective truth, but it never reaches it, which is the essence of the uncertainty of judicial decisions and may lead to injustice. In this article, the uncertainty of judicial decisions will be discussed and 
analyzed mainly from the perspective of the latter one - the judicial adjudicator (i.e., the judge), and accordingly, corresponding measures will be proposed to decrease the uncertainty of the decisions and increase the judicial justice.

\section{Internal Factors of Judicial Uncertainty}

Judicial uncertainty can be analyzed from the point of view of the judge, the arbiter of justice, by looking at both internal and external factors. In some studies, the internal factors include psychological variables related to the personality of decisionmakers. Identified elements include commitment, the sense of responsibility, honesty, and understanding the appropriate distance to take from particular facts or persons. [3, 4] The internal factors can be divided into three aspects: the quality and competence, the inner beliefs and the professional characteristics.

\subsection{The Quality and Competence of Judicial Adjudicators}

A crucial reason for the uncertainty of judicial decisions is the low quality and competence of judges in their practice. Judges are required to be well proficient in the law, with solid professional knowledge and skillful legal skills, as well as well-understanding of society, being well versed in matters of fact, and having the ability to analyze and judge things in a comprehensive manner. Depending on the complexity of the case, a judicial decision can be considered of high quality if it satisfies the requirements of internal and/or external justification established by the theory of legal argument. [5-8] The attitudinal model states that the academic and social background of judges explains their preferences and the orientation of their decisions. [9] Furthermore, in an empirical case study consisting of a sample of 11 Helsinki district court verdicts from 2014-2017, which features a medical controversy concerning traumatic brain injury (TBI) diagnostics, it was noted that the difficulties judges face in evaluating the medical expertise result from epistemic asymmetries between legal and medical professionals, which reinforce the uncertainty of judicial decisions. [10]

As a result of the judges' low business quality and ability, they do not have the ability to link the legal provisions with the case for rational thinking, resulting in a lapse of judgment and improper ruling and leading to uncertainty in the outcome of the case.

\subsection{The Inner Beliefs of the Judicial Adjudicators}

The inner beliefs of a judicial adjudicator are the result of his or her belief in the law and his or her understanding and recognition of the basic principles of judicial ethics, professional ethics, professional honor, and sense of responsibility. Judges must revere the law and take it as their second life. If judicial adjudicators do not have an uncompromising faith in the law, it will bring about great uncertainty in judicial decisions. Moreover, the law is the last line of defense for social remedies and judicial adjudicators should have a high moral character and professional integrity. If there is a lack of moral faith and the sense of professional honor and responsibility, judges may lose their rationality in judicial decisions to the extent of not respecting objective facts or even distorting them, resulting in unjust outcomes. VP Ivanskiy noted that the impartiality of the judge's personality is formed not only by intellectual, moral, and volitional spheres, but also by emotional ones, where the latter includes conscientiousness and receptivity. It is precisely the judges' behavior, their decision-making, that determines their beliefs based on conscience, which is the source of true law, called intuitive law. [11]

\subsection{The Professional Characteristics of the Judicial Adjudicators}

On one hand, the professional attributes of judicial adjudicators include the practical experience, judicial habits and professional ways of thinking that are unique to different judges. The professional characteristics have to do with the set of skills that enable political actors to perform their work correctly. [12, 13] In this regard, formal education and political experience through elected office or party positions are the elements which are cited most often. [14]

Academic training is a measure of the experience, knowledge, skills, and expertise required to approach legal problems and resolve complex legal disputes. Legislative policy research [12], studies of bureaucracy [15], and other research related to the quality of public policies [16] refer to this accumulation of experience as "professionalism." As judges have been practicing law for various periods of time and have acquired distinctive legal experience, their ability to apply the law, to analyze, to judge right and wrong, to evaluate and analyze evidence, and to organize and manage the whole courtroom activity will differ, which will lead to different judicial outcomes and create uncertainty in judicial decisions.

On the other hand, judicial behavioral habits, as stable and habitual behavioral tendencies and patterns formed in long-term judicial professional habits, reflect the judicial behavioral tendencies of judicial adjudicators in judicial decisions. As there are distinctions between good and bad judicial habits, as well as between individual judges, judicial habits of behavior have a significant impact on judicial uncertainty for different judges. To avoid the uncertainty caused by judicial behavioral habits, algorithms, from simple automation to machine learning, have been introduced into judicial contexts to ostensibly increase the consistency and efficiency of legal decision making. Nevertheless, due to the differences in the algorithmic mechanism, the uncertainty of judicial decisions is still not completely avoidable [17].

Besides, the professional thinking of judges is also a critical internal factor that has a significant impact on the uncertainty of judicial decisions. The professional thinking of a judge, as a judicial adjudicator, should and must be legal thinking, a process of thinking that makes the best choices about legal rules, principles and techniques within the framework of the rule of law. The effectiveness of the justice 
system can significantly increase if the judge has a special state of professional legal awareness based on a progressive type of legal thinking, which is represented by a scientifically based integrative concept of law understanding. [18] The job of the judge is to constantly strive for the legality of the decision in the belief that there is objectivity in the law. But judges, as ordinary human beings, often cannot reproduce $100 \%$ of the facts of a case that occurred in the past as they were. What the judge sees is only the evidence, and what he perceives can only be the "facts" that the evidence proves. As a result, due to the procedural aspects of the collection, collation, examination and determination of evidence and the statute of limitations, the evidence may be incomplete or lacking in probative value, thus leading to bias in the determination of facts and thus to uncertainty in judicial decisions.

\subsection{Summary}

It should be noted that the internal factors of judicial uncertainty are constituted by the personalities, qualities, abilities, conduct and ways of thinking of the judges themselves. In contrast, the external factors of judicial uncertainty stem from institutional or social constraints.

\section{External factors of Judicial Uncertainty}

As with the discussion of internal factors, an analysis of the external factors that contribute to judicial uncertainty can also be made from three perspectives: the political system, the judicial system and public opinion. Unlike the internal factors, there is a clear correlation and a strong logic between these three factors.

\subsection{The Political System}

Hamilton argues that the importance of the court is not commensurate with the position it often occupies. In contrast to the legislative and executive branches, the judiciary had neither military nor financial power, so it had neither coercion nor will, but only judgement, and it had to rely on the power of the executive to enforce its judgement, making it the weakest of the three separated powers. [19] Montesquieu even once said that "Judicial power is in a way non-existent". [20]

Firstly, the foremost factor contributing to the uncertainty of judicial decisions in the political system is the administrativeization of the external form of judicial power, as the judiciary has not fully assorted its relationship with the party committee, the government and the NPC. The administrativeization of the external form of judicial power inevitably limits the independence of the courts and leads to uncertainty in judicial decisions.

Secondly, the administrativeization of the external form of judicial power, the uniformity of the jurisdictional division of the judiciary and the jurisdictional division of the executive power ultimately led to the localization of judicial power. As the courts are subject to the dictates of local governments at all levels and cannot be independent in terms of personnel, money and materials, it has resulted in a high degree of dependence of the judiciary on local government authorities, and local interests have objectively become part of the interests of the local judiciary. Hence, it is not surprising that there is uncertainty in judicial decisions when adjudicating cases.

Thirdly, the localization of judicial power has led to the localization of judicial personnel, especially judicial adjudicators, which has combined with the localization of judicial power to form judicial local protectionism. The territoriality and limitations of the sources of judicial adjudicators have created interpersonal relationships that are easily entangled in local complexes, making judicial local protectionism the subconscious of a significant number of officials. As a result, the uncertainty of judicial decisions becomes inevitable.

\subsection{The Judicial System}

According to Lord Birmingham: "The complete functional independence of the judiciary from the executive is the most fundamental element of the rule of law." [21] Lord Horton, on the other hand, argued that "Separation is an essential element of democracy." [22]

Firstly, the internal formal administrativeization of judicial power manifests itself in a substantive leader-led relationship between higher and lower courts on the one hand, and in the administration of personnel within the courts on the other. As a result, judges are not equal to judges, they have different administrative levels, and higher-level judges can have the right to correct the judgments of lower-level judges, which tends to produce uncertainty in judicial decisions.

Secondly, the existence of the trial committee system and the separation of adjudication. For cases with complex interpersonal relationships, judges refer cases to the trial committee in order to eliminate or reduce the pressure suffered by them personally, resulting in the separation of adjudication, which can easily lead to the consequences of uncertainty in judicial decisions.

Thirdly, the imperfect mechanism for the appointment and removal of judges. The appointment of judges has a strong administrative overtone, and judicial judges sometimes succumb to the pressure of power to make decisions that are contrary to objective facts, taking into account their own career prospects and interests, thus creating uncertainty in judicial decisions.

\subsection{The Public Opinion}

The phenomenon of group polarization often arises in the ferment of public opinion. For decades, published articles have consistently reported a significant, positive relationship between public opinion and Supreme Court output. [23] Group polarization is a phenomenon in which the members of a group discuss an issue and then make a decision that is more extreme than the views of any of the members of the 
group before the discussion. [24] Vulnerability to public opinion is a manifestation of the lack of professionalism in China's judicial activities. As judges' adjudication process and results are subject to the influence of various values, and only adjudicative acts and judgments that conform to the dominant values of society can have high social acceptability, judges are thus required to respect established legal and cultural traditions and values, and to take into account relevant customs and ethical norms to determine and achieve justice in each case. This may give rise to the phenomenon of "public sentiment" over legal reasoning, leading to uncertainty in judicial decisions.

\subsection{Summary}

Although the above points are only external factors in the uncertainty of judicial decisions, we should be clear that starting from the institutional level as an external factor often has the most effective, direct and rapid effect in reducing the uncertainty of judicial decisions. At the same time, the impact of internal factors on the uncertainty of judicial decisions will also be inhibited or even diminished to a certain extent.

\section{How to Mitigate the Uncertainty of Judicial Decisions from the Perspective of the Judicial Adjudicator}

In order to reduce the uncertainty of judicial decisions from the perspective of judicial adjudicators, it is undoubtedly necessary to start with both internal and external factors. The internal factors are the improvement of the competence, quality and integrity of the judiciary and the professionalization of the judges; the external factors are the institutional and systemic reforms, especially the independence of the judiciary.

\subsection{Internal Factors to Mitigate the Uncertainty of Judicial Decisions}

First of all, the academic qualifications of judicial adjudicators should be improved. The educational requirement for judges in western developed countries is a university degree in law, and China should also establish the principle of the antecedent of university legal education for the profession of judge. Only by raising the academic bottom line of judges' qualifications can we adapt to the needs of China's economic and social development and the complexity of trials. While judges are selected with strict academic qualifications and the threshold of the judiciary is raised to guarantee the quality of our judiciary in terms of hard conditions, serving judges who have already met the academic requirements should be encouraged to continue their further education and eventually turn to a lifelong education. As a judge is an elite profession, the ultimate goal of the professionalization of judges is also elitism. Although China is a country with statute laws, due to the incompleteness of written laws, the quality of judges with considerable discretion has a direct and important impact on judicial efficiency. Using the data of the chief justices of Higher People's Court in China, Chen G finds that the professional background of judges has significantly affected the judicial efficiency measured by the resolution rate; the resolution rate of the courts whose chief justices of Higher People's Court graduated from the law school is about 2.5 percentage points higher than that in other regions. [25] Only when a judge has more and deeper professional legal knowledge can he have the courage and wisdom to pursue justice, thus effectively reducing the uncertainty of judicial decisions.

Secondly, we ought to establish the modern judicial concept of "neutrality, equality, transparency, fairness, efficiency, independence and civilization" as the core, and to deepen the awareness of responsibility and the role of the judicial adjudicator. In the book How Judges Think, Richard Posner summarizes the judicial behavior and thinking patterns of American judges. Posner argues that judges are not saints, that their behavior is driven by desire, and that they seek the same good things that ordinary people seek, such as power, fame, income, self-respect, respect and leisure. A judge's political preferences or other factors outside the law shape his judicial preconceptions, which in turn directly influence his responses to cases, such as his personality traits and his life and professional experience. [26]

At the level of spiritual and cultural concepts, judges should constantly establish a modern judicial philosophy, so that they can think about, treat and resolve all kinds of disputes with a unique value orientation through their own choice based on a rational analysis of the essential characteristics and operation rules of judicial power. So that justice, the ultimate goal of justice, and the modern judicial philosophy can be rooted in the hearts of judicial judges, and they can develop a strong sense of mission, responsibility and role, to carry out judicial practice in earnest and to continuously realize their social value.

Thirdly, with the goal of establishing the values of justice and efficiency, the common beliefs and value pursuits of judicial adjudicators should be modelled. From the level of spiritual and cultural values, in addition to the faith in law and the pursuit of the value of the rule of law, required by the rule of law society, special professional beliefs and value pursuits should also be formed and adapted to judicial adjudication activities, specifically to maintain judicial justice and judicial efficiency at all times as the goal, to form an atmosphere in the group of judges to advocate rules and procedures, promoting social justice through judicial decisions.

\subsection{External Factors to Mitigate the Uncertainty of Judicial Decisions}

Complete judicial independence includes two aspects: the independence of the courts and the independence of judges. The independence of the courts means that the people's courts are free from interference by administrative organs, 
social groups and individuals in the exercise of judicial power in accordance with the law. This requires that the people's courts should not only be independent of the executive and legislative branches in their institutional set-up, but also free from interference from other branches in the exercise of judicial power in accordance with the law.

The independence of judges means that within the courts, judges should exercise their judicial power in accordance with the law. On the one hand, it means that the judicial magistrate shall hear cases in a sole and collegial manner, subject only to the law and without undue interference from other judges within the court. On the other hand, the independence of judges also means that the judges of lower courts shall exercise their judicial power in accordance with the law and without undue interference from higher courts. In addition, judicial adjudicators should also treat public opinion correctly and not be interfered with by it.

First of all, the independent exercise of judicial power as stipulated in the Constitution must be upheld. "From the point of view of the domination of things, to prevent the abuse of power, it is necessary to restrain power by power." [20] Although China's constitution clearly provides for a system of independent exercise of judicial power by the people's courts, the institutional design of the judiciary and the external environment makes it difficult to implement this provision. From the perspective of the relationship between judicial independence and the leadership of the Party, judicial independence in China is judicial independence under the leadership of the Party. The provisions of our Constitution and the Party's constitution both reflect that the Party's leadership of judicial work is mainly the leadership of guidelines and policies, rather than directly intervening in the specific trial work or making approval of the adjudication of cases. The Party Committee and the judiciary have their own duties and cannot replace or confuse each other. Furthermore, in terms of the relationship between the courts and the authorities, it is important to correctly understand that the judiciary should be accountable to the National People's Congress, as stipulated in the Constitution, and this accountability means that through the strict implementation of the laws enacted by the National People's Congress, efforts should be made to achieve impartiality in adjudication, thereby realizing the will and interests of the people as a whole.

Secondly, local interference and local protectionism should be prevented and a vertical court system should be established. In the current judicial system, the courts are set up in line with the administrative divisions, and there are various interests between the courts and the administrative organs in terms of personnel and finance. The specific setting of jurisdictions in the US within particular states also does not overlap with administrative jurisdictions. For example, Alabama is divided into three jurisdictions, North, Central and South, with each of these different jurisdictions divided into different branches, each of which is subdivided into a number of counties, and the courts are located in one of these administrative areas. [27]
Therefore, the courts should be freed from the framework of administrative divisions and set up in large judicial districts across provinces and regions, and the personnel and finances of the courts should also be freed from the shackles of local governments and a vertical personnel and financial system should be established from the central to the local courts, so as to prevent local protectionism and to solve the phenomenon that the regulations of jurisdictional objections or cases without jurisdiction vary greatly from region to region.

Thirdly, the relationship between the higher and lower courts should be adjusted. The relationship between the higher courts and the lower courts is not a leader-and-led relationship, but rather "a relationship of adjudication", which is of supervision-and-supervised between two different legal procedures for handling of disputes between parties, rather than a relationship of command and obedience as in the case of administrative bodies above and below.

Fourthly, the administrative approach to the internal operation of the courts should be amended to guarantee the independence of judges. In order to implement the independence of judges, it is necessary to implement the authority of the collegiate court and the single judge according to the law, and also to guarantee the independence of judges from outside interference from the system. In this regard, firstly, a stable system or even a life-long system should be established for judges, whereby any person who becomes a judge should remain stable for a considerable period of time, and judges should not be removed from office without fault. Secondly, a full-time system for judges, i.e., judges should be prohibited from holding part-time positions, so that judges cannot be influenced by various institutions, social organizations and individuals. Thirdly, the recusal system is needed to ensure that judges' decisions are not influenced by various factors, such as geography, relatives and family, and that the law is truly strictly enforced.

\section{Conclusion}

One of the fundamental values of the existence of justice is that it psychologically satisfies the human need for stability and certainty, so that imbalances of power and responsibility can be balanced and disputes can be settled. The uncertainty of judicial decisions is a fundamental problem that the modern rule of law must face, and its understanding and resolution is crucial to the direction of the rule of law and its future.

The uncertainty of judicial decisions is certainly influenced by the internal and personal factors of the judges, but we can see that the external factors, such as the deficiencies of the system and institutions, play a direct and more profound role. In the absence of a system, the emphasis on "judicial certainty" is unlikely to bring about any substantial change, but what is needed is an institutional guarantee of judicial certainty.

Under such conditions, it is of course necessary for judges to maintain their independence, enforce the law strictly and administer justice impartially, and contribute to the 
establishment of a society governed by the rule of law, but it is even more necessary for us to create conditions to enhance judicial independence and impartiality through judicial reform, so as to reduce the uncertainty of judicial decisions.

\section{Acknowledgements}

The authors declare no conflict of interest. This work was supported by Humanities and Social Science Fund of Ministry of Education of China (Grant Number 19YJCZH235; PI: Zheng ZANG) and the Major Projects of China's Ministry of Education's Key Research Center for Humanities and Social Sciences (Grant Number 17JJD720007).

\section{References}

[1] Pásara, Luis. 2006. Cómo Sentencian Los Jueces Del Distrito Federal en Materia Penal? México: Editorial de la Universidd Nacional Autónoma de México.

[2] Pásara, Luis. 2000. Las Decisiones Judiciales en Guatemala. Managua: Minugua.

[3] Weber, Max. 1967. El Político y el Científico. Madrid: Alianza.

[4] Caselli, Francesco, and Máximo Morelli. 2000. "Bad politicians" Discussion Paper 134. Institute for Empirical Macroeconomics. Federal Reserve Bank from Minneapolis.

[5] Ribeiro, Gerardo T. 2003. Teoría de la Argumentación Jurídica. México: Universidad Iberoamericana.

[6] Atienza, Manuel. 1997. Las Razones Del Derecho. Teorías de la Argumentación Jurídica. Madrid: Centro deEstudios Políticos y Constitucionales.

[7] Atienza, Manuel. 1994. "Las razones del Derecho. Sobre la justificación de las decisiones judiciales" Isonomía: Revista de Teoría y Filosofía Del Derecho 1: 52-69. URL: http://www.cervantesvirtual.com/nd/ark:/59851/bmcm61w0.

[8] Alexy, Robert. 1978/2010. Teoría de la Argumentación Jurídica: La Teoría Del Discurso Racional Como Teoría de la Fundamentación Jurídica. Lima: Palestra Editores.

[9] David, Rohde, and Harold Spaeth. 1976. Supreme Court Decision Making. San Francisco, C. A: Freeman.

[10] Taipale J. Judges' socio-technical review of contested expertise. Social Studies of Science. 2019; 49 (3): 310-332. doi: $10.1177 / 0306312719854538$

[11] VP Ivanskiy. The concept of judge's impartiality in administering justice: basic conceptual approaches. Research Gate. 2021. doi: 10.24833/2073-8420-2021-1-58-26-34.
[12] Alcántara, Manuel. 2012. El Oficio Del Politico. Madrid: Tecnos.

[13] Martínez, Rosón, and María del Mar. 2008. "Legislative Careers: Does Quality Matter?" In Manuel Alcántara, ed. Politics and Politicians in Latin America. Boulder: Lynne Riemer.

[14] Fiorina, Morris P. 1994. "Divided Government in American States: A Biproduct of Legislative Professionalism?" American Political Science Review 88 (02): 304-16. URL: https://www.jstor.org/stable/2944705 doi: 10.2307/2944705.

[15] Scartascini, Carlos, Pablo Spiller, Ernesto Stein, and Mariano Tommasi, eds. 2011. El Juego Político en Am? Erica.

[16] Zuvanic, Laura, Mercedes Iacoviello, and Ana Laura RodrÍguez Gustá. 2010. "The Weakest Links: The Bureaucracy.

[17] Travis Greene, Galit Shmueli, Jan Fell, Ching-Fu Lin, Mark L. Shope, Han-Wei Liu. The Hidden Inconsistencies Introduced by Predictive Algorithms in Judicial Decision Making. Tue, 1 Dec 2020 06: 12: 30 UTC. arXiv: 2012.00289 [cs. CY].

[18] Kanischev V P, Palekha R R, Fedotova O A, et al. Judicial Ethics: Moral and Legal Aspects in the Context of a Scientifically Based Integrative Concept of Legal Understanding. 2020.2 doi: 10.37399/issn2072-909X.2020.10.54-61.

[19] Hamilton, Jay, Madison, The Federalist Papers, The Commercial Press, 1980, p. 191.

[20] Secondat C D, Montesquieu B D. Montesquieu: The Spirit of the Laws [J]. 1989.

[21] Statement by Lord Brightman, in Hansard, HL cols 119-120, September 8, 2003.

[22] Lord Cooke, The Law Lords: an Endangered Heritage, L. Q. R. 2003, 119 (Jan), 49-67.

[23] Johnson B, Strother L. The Supreme Court's (Surprising?) Indifference to Public Opinion [J]. Political Research Quarterly, 2020, 74 (1).

[24] David Isenberg, [J], 50, Personality and Soc Psych 1141 (1986). Quoted in Sun Xiaowan, "Public Opinion, Subject Matter and Information Symmetry in Public Cases" [J], Chinese Law Journal, Vol. 3, 2010.

[25] Chen G, Economics S O. Which Weighs in Selection of Judges, Education Background or Profession: Evidence from the Improvement of Judicial Efficiency [J]. Journal of Guangdong University of Finance \& Economics, 2019.

[26] Posner R A. How Judges Think [M]. 2010.

[27] http://policy.mofcom.gov.cnlenglish/flaw!lfetch.actionid=b22 6f749-58e1-4030-8b13-16964a48af44\&pager.pageNo=6. 